\title{
Repair of large airway defects with bioprosthetic materials
}

\author{
Brooks V. Udelsman, MD, ${ }^{\mathrm{a}}$ Jessica Eaton, BA, ${ }^{\mathrm{b}}$ Ashok Muniappan, MD,${ }^{\mathrm{c}}$ Christopher R. Morse, MD, \\ Cameron D. Wright, MD, ${ }^{c}$ and Douglas J. Mathisen, $\mathrm{MD}^{\mathrm{c}}$
}

\begin{abstract}
Objective: Patients with complicated airway defects that exceed the limits of primary repair represent a challenging clinical problem and require alternative techniques for repair. The aim of this study was to evaluate bioprosthetic reconstruction of large tracheal and bronchial defects.

Methods: Retrospective chart review of patients treated at a single tertiary center from 2008 to 2015 who underwent repair of tracheal or bronchial defects with a bioprosthetic device, namely aortic homograft or acellular dermal matrix.
\end{abstract}

Results: Eight patients, 3 men and 5 women with a mean age of $54 \pm 13$ years, underwent closure of complex central airway defects with bioprosthetic material. All but 1 patient underwent prior operative or stenting procedures. Three patients had isolated airway defects, whereas 5 had fistulas between the airway and enteric tract. Defects involved the membranous wall of the trachea $(n=5)$, the anterior wall of the trachea $(n=1)$, or the main stem bronchus $(n=2)$. Five reconstructions were with aortic homograft and 3 with acellular dermal matrix. Bioprosthetic material was buttressed with muscle flap $(n=4)$, omentum $(n=2)$, or left unbuttressed $(n=2)$. The airway defect was successfully closed in all patients. There was no postoperative mortality or recurrence of the airway defect in short-term follow-up. Two patients required debridement of granulation tissue and 1 additional patient required airway balloon dilation. Progression of underlying metastatic disease explained the majority of long-term mortality $(75 \%)$.

Conclusions: Bioprosthetic materials represent a viable option for management of large airway defects, including airway-enteric fistulae, that exceed the limits of primary repair. (J Thorac Cardiovasc Surg 2016;152:1388-97)

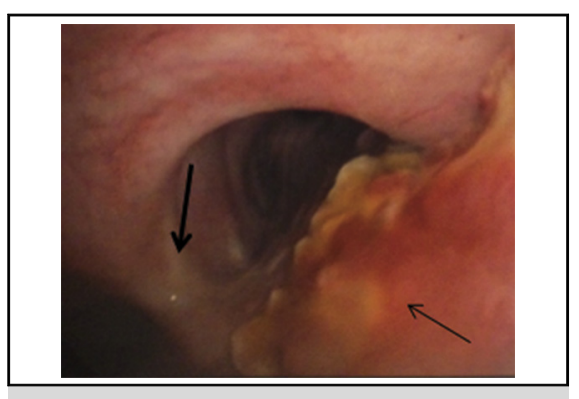

Aortic homograft repair (small arrow) extending just proximal to the carina (large arrow).

\section{Central Message}

Bioprosthetic materials represent a viable option for management of airway defects, including airway-enteric fistulae, that exceed the limits of primary repair.

\section{Perspective}

Central airway defects whose size and complexity preclude primary repair present a challenging clinical problem. We examined the role of bioprosthetic materials (aortic homograft and acellular dermal matrix) in the repair of noncircumferential defects. In our experience these materials provide airtight closure and correction of complex defects in otherwise difficult-to-manage patients.

See Editorial page 1233.
Large central airway defects may be acquired in a variety of situations, whether it be from primary pathology or as a consequence of operative management of the airway. ${ }^{1-3}$ Primary repair, which often entails resection and reconstruction, is the preferred treatment of large airway defects. Central airway defects are even more complex when there is fistulous communication with the

From the Divisions of ${ }^{\mathrm{a}}$ General Surgery and ${ }^{\mathrm{c}}$ Thoracic Surgery, Massachusetts General Hospital, Boston, Mass; and ${ }^{\mathrm{b}}$ University of Louisville School of Medicine, Louisville, Ky.

Read at the 96th Annual Meeting of the American Association for Thoracic Surgery, Baltimore, Maryland, May 14-18, 2016.

Received for publication May 2, 2016; revisions received July 11, 2016; accepted for publication July 15, 2016.

Address for reprints: Brooks V. Udelsman, MD, Division of General Surgery, Massachusetts General Hospital, 55 Fruit St, Boston, MA 02114 (E-mail: budelsman@ partners.org).

0022-5223/\$36.00

Copyright (c) 2016 by The American Association for Thoracic Surgery

http://dx.doi.org/10.1016/j.jtcvs.2016.07.074 esophagus. In these cases, optimal management requires primary closure of both defects and interposition of robust vascularized tissue. Whereas tracheal defects up to $5 \mathrm{~cm}$ may be resected with the help of laryngeal and hilar release, in larger defects and in patients with unfavorable characteristics, primary correction may not be possible. ${ }^{4}$ Alternative methods must be used in these patients to close acquired airway defects and eliminate the complications associated with persistent fistulas.

Bioprosthetic materials such as aortic homograft and acellular dermal matrix have been used successfully in a variety of reconstructive applications, including repair of

Scanning this QR code will take you to the article title page. To view the AATS 2015 Webcast, see the URL at the end of the article. 


\section{Abbreviation and Acronym \\ HBOT $=$ hyperbaric oxygen therapy}

pharyngeal and esophageal defects. ${ }^{4-7}$ Additionally, a small number of patients with complex airway defects of the trachea and bronchi have undergone successful repair with bioprosthetic materials. ${ }^{8-10}$ Bioprosthetics have several potential advantages over synthetic materials including ease of handling, minimal immunogenic response, and potential for tissue ingrowth. The aim of this study was to evaluate our experience with surgical management of complex airway defects with acellular dermal matrix and aortic homograft patches. We reviewed the patient characteristics, operative techniques, and postoperative management associated with successful closure.

\section{METHODS}

\section{Patient Selection and Chart Review}

We reviewed the medical records of all adult patients who underwent operative repair of tracheal or bronchial defects using bioprosthetic material with either acellular dermal matrix or aortic homograft at a single tertiary medical center. Patients with tracheal and bronchial defects that were amenable to primary repair were excluded from the study. The electronic medical record was reviewed for demographic characteristics, operative details, and outcome variables. The Social Security Death Index was consulted to determine vital status of 2 selected patients. The Institutional Review Board at Massachusetts General Hospital approved this retrospective chart review and waived informed consent for participation in the study.

\section{Operative Management}

All patients underwent bronchoscopic evaluation before repair to establish the location and size of the tracheal or bronchial defect. Computerized axial tomography imaging as well as esophagoscopy were also used to assess defects especially in cases of associated aerodigestive fistula. Before scheduling for operative correction underlying pneumonia was treated in an effort to prevent postoperative infection and contamination of the bioprosthetic. Based on the location of the defect, single-lung or 2-lung ventilation was performed during the procedure. In the operating room, airway defects were debrided to obtain grossly healthy tissue margins for repair. Defects were repaired with either acellular dermal matrix or banked aortic homograft patch. In no patient was a bioprosthetic used as a circumferential conduit. The choice of bioprosthetic material was based on surgeon preference.

After standard preparation the bioprosthetic was trimmed to size and meticulously sutured to healthy tracheal or bronchial mucosa using interrupted Vicryl suture (Ethicon Inc, Somerville, NJ). In the case of acellular dermal matrix the bioprosthetic was sutured so that the dermal side faced the airway lumen. Similarly, the aortic homograft was implanted so that the luminal aspect of the bioprosthetic faced the airway lumen. Before implanting the aortic homograft was perforated with a 16-gauge needle to encourage tissue ingrowth and neovascularization. These perforations did not compromise the pneumostasis of the repair. Only after the repair was deemed competent was additional buttressing with muscle flaps or omentum performed. Most commonly the latissmus dorsi and intercostal muscles were used to buttress the bioprosthetic, but there were cases in which strap muscle and omentum were used. The buttress was secured using a horizontal mattress stitch to tack the back of the bioprosthetic to the muscle or omentum. The choice of buttress material was based on surgeon preference and ability to harvest healthy tissue while preserving the vascular supply.

\section{Postoperative Care}

Immediately after surgery patients were transported to the surgical intensive care unit before transfer to a floor unit. Postoperative care was variable, but included antibiotic treatment, serial bronchoscopy, speech and swallow evaluations, video fluoroscopic swallow studies, and hyperbaric oxygen therapy (HBOT).

\section{RESULTS \\ Patient Characteristics and Etiology of Airway Defect}

The study identified 8 patients with tracheal and bronchial defects repaired with bioprosthetic materials between 2008 and 2015. It should be emphasized that all patients possessed complex defects that due to size, location, and challenging patient factors were preoperatively deemed not amenable to primary repair (Figure 1). These patients represent a small minority of the 342 patients treated within the same time period who were able to undergo conventional repair (Figure 2). There were 3 male and 5 female patients with a mean age of $54 \pm 13$ years. Each patient included in the study underwent a preoperatively planned repair with a bioprosthetic and no repair was aborted intraoperatively. Patient data are summarized in Table 1. Patients were followed for a median period of 150 days with a range of 2 months to 6 years. All patients had substantial comorbidities, including prior esophageal, tracheal, and thyroid surgery. The etiology of the airway defect in the series varied, and included HIV/AIDs-associated esophagitis, malignancy, mesh erosion, and complications secondary to prolonged intubation. Three patients had also received prior radiation therapy to the neck or chest.

\section{Surgical Approach}

The goal of operative intervention in all cases was repair of the airway defect and closure of any associated fistula. Secondary goals in select cases included airway decannulation and resumption of oral nutrition. The majority of patients had defects that were localized to the membranous wall of the trachea. However, 2 patients had defects that involved the mainstem bronchus or bronchus intermedius, whereas 1 patient had a large defect of the anterior wall of the trachea (Table 2). Surgical approach to the airway defect was determined by the location of the lesion, with the majority accessed via a right posterolateral thoracotomy (Table 3). Five patients (63\%) required interruption of a fistula to the esophagus or gastric conduit from prior esophagectomy. Esophageal or gastric defects were resected in 3 patients and primarily repaired with a double layer closure in 2 patients. One patient was left in discontinuity with an end pharyngostomy. In 6 of 8 patients, the repair was buttressed with pedicled muscle flap or omentum. The 

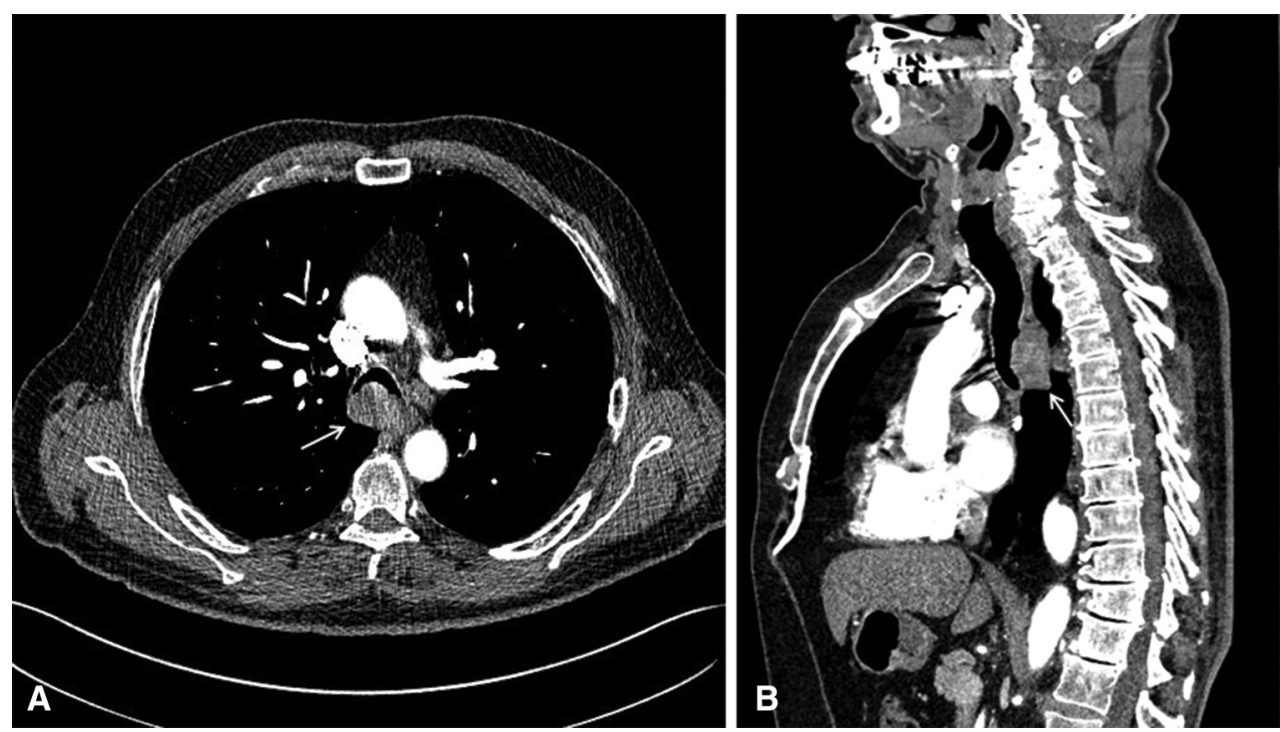

FIGURE 1. Computed tomography scan of the neck and chest demonstrating in both axial (A) and sagittal (B) views a large soft tissue mass involving the trachea and extending from the superior aspect of the aortic arch to the inferior aspect of the carina. Given its size and location, the lesion was not suitable for primary repair.

selection of buttressing material was determined by location of the lesion, availability of healthy nonirradiated tissue whose vascular pedicle could be preserved, and surgeon preference. In 1 patient requiring closure of airway defect caused by mesh erosion from prior tracheoplasty for tracheobronchomalacia, polypropylene mesh was sutured to the bioprosthetic without additional tissue buttressing. In all cases, the buttress was secured to the bioprosthetic using a horizontal mattress stitch. In this way the buttressing muscle or omentum both supported the bioprosthetic in the event of a leak and tacked it up to prevent the bioprosthetic from becoming malacic.

\section{Postoperative Course}

All patients underwent successful closure of the airway defect. Defects repaired with either acellular dermal matrix

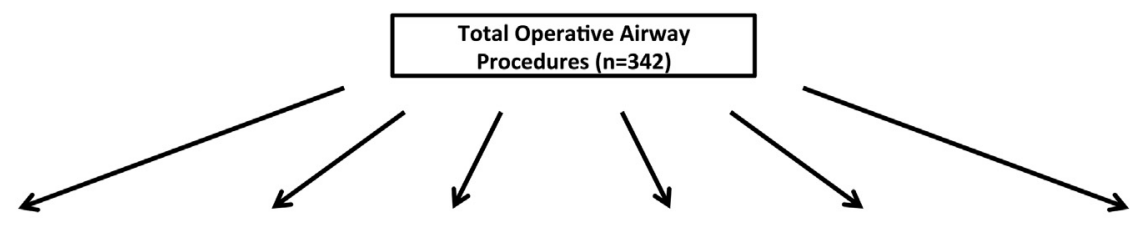

Underlying Pathology

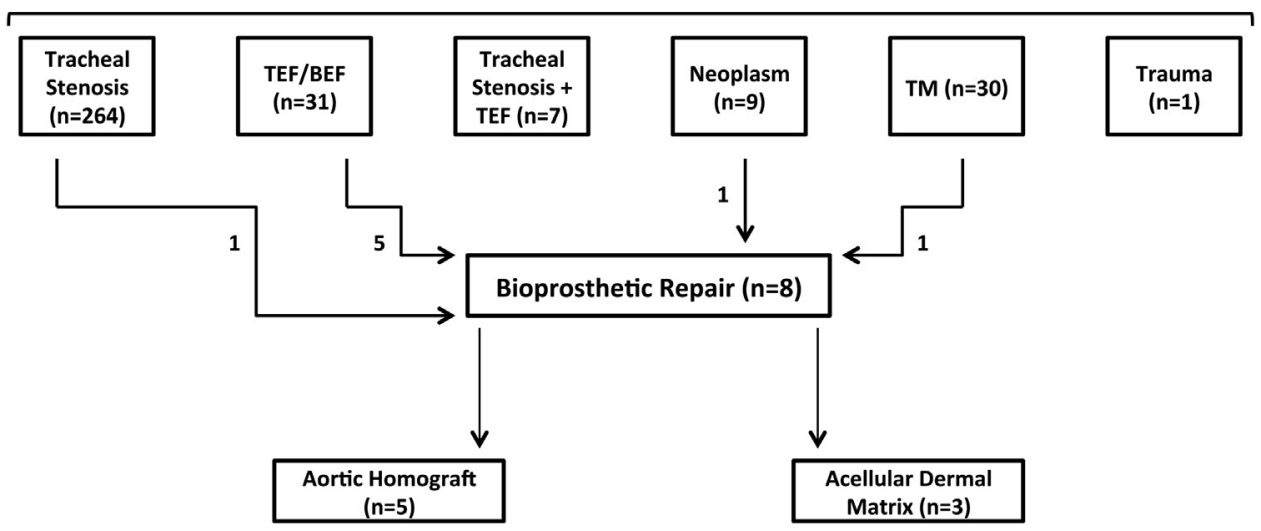

FIGURE 2. Patients undergoing airway repair at single tertiary care center between 2008 and 2015 . Out of a total of 342 cases only 8 required bioprosthetic repair. Underlying etiology of defects requiring bioprosthetic repair included tracheal stenosis, tracheoesophageal fistula (TEF)/bronchoesophageal fistula $(B E F)$, neoplasm, and tracheomalacia $(T M)$. Given the wide range of patient age, cases of congenital stenosis were not included in the study analysis. 
TABLE 1. Patient characteristics

\begin{tabular}{|c|c|c|c|c|c|c|}
\hline Patient & Sex/age, $y$ & $\begin{array}{l}\text { ASA } \\
\text { class }\end{array}$ & Etiology of airway defect & Relevant comorbidities & $\begin{array}{c}\text { Prior airway/esophageal } \\
\text { procedure(s) }\end{array}$ & $\begin{array}{c}\text { Prior chest } \\
\text { and/or neck } \\
\text { radiation }\end{array}$ \\
\hline 1 & Male/38 & 2 & Bronchoesophageal fistula & HIV/AIDs, esophagitis & Esophageal stent placement & No \\
\hline 2 & Female/73 & 3 & Tracheogastric fistula & $\begin{array}{l}\text { Esophageal stenosis, esophageal } \\
\text { squamous cell carcinoma, } \\
\text { thyroid cancer status posttotal } \\
\text { thyroidectomy }\end{array}$ & Pharyngolaryngeal gastrectomy & Yes \\
\hline 3 & Male/46 & 2 & Erosion of HDPE mesh & Severe tracheobronchial malacia & $\begin{array}{l}\text { Membranous wall tracheoplasty } \\
\text { with marlex mesh }\end{array}$ & No \\
\hline 4 & Female/70 & 3 & TEF secondary to malignancy & $\begin{array}{l}\text { Esophageal squamous cell } \\
\text { carcinoma }\end{array}$ & Esophageal stent placement & Yes \\
\hline 5 & Female/54 & 3 & $\begin{array}{l}\text { TEF secondary to esophageal } \\
\text { stent erosion }\end{array}$ & $\begin{array}{l}\text { Hodgkin lymphoma, esophageal } \\
\text { stenosis }\end{array}$ & Esophageal stent placement & Yes \\
\hline 6 & Female/59 & 3 & $\begin{array}{l}\text { TEF secondary to postintubation } \\
\text { injury }\end{array}$ & Stroke & Tracheostomy & No \\
\hline 7 & Female/36 & 2 & $\begin{array}{l}\text { Anastomotic dehiscence in setting } \\
\text { of high-dose corticosteroids }\end{array}$ & $\begin{array}{l}\text { Spinal cord tumor C4-C5, } \\
\text { Tracheal stenosis }\end{array}$ & $\begin{array}{l}\text { Failed tracheal resection and } \\
\text { reconstruction }\end{array}$ & No \\
\hline 8 & Male/57 & 2 & $\begin{array}{l}\text { Partial tracheal resection } \\
\text { secondary to neoplasm } \\
\text { excision }\end{array}$ & $\begin{array}{l}\text { Adenoid cystic carcinoma of } \\
\text { trachea }\end{array}$ & None & No \\
\hline
\end{tabular}

$A S A$, American Society of Anesthesiologists; HDPE, crystalline polypropylene and high density polyethylene; TEF, tracheoesophageal fistula

or aortic homograft demonstrated patency without evidence of air leak from the reconstruction. Enteric defects after fistula resection were either closed primarily or resected. There was no short-term postoperative mortality.

Three patients were extubated at the end of the case, whereas 5 patients were transported on a ventilator to the surgical intensive care unit. Two of these 5 patients were decannulated within the following weeks, whereas all were eventually free of mechanical ventilation. Three patients required long-term airway appliances with either tracheostomy or a tracheal T-tube.

Although the majority of patients resumed oral intake, 1 patient with extensive history of prior surgical procedures and tracheogastric fistula was left in discontinuity with a pharyngostomy. Oral diet was not resumed in an additional patient with a persistent neurocognitively debilitated state that existed preoperatively. Another patient with a tracheoesophageal fistula repair and cervical esophagostomy was eventually able to resume an oral diet but remained dependent on tube feeds to meet caloric needs (Table 4).

All patients, regardless of the bioprosthetic material used, developed granulation tissue at the site of airway reconstruction. Two patients required further debridement of granulation tissue. One patient had evidence of stricture in the tracheal repair and underwent balloon dilation. Serial bronchoscopies revealed granulating tissue with mild contracture; however, airway patency was maintained (Figure 3). One patient underwent planned hyperbaric oxygen therapy in the postoperative period to promote healing and tissue ingrowth. This patient received treatments twice daily for 10 days. No adverse effects of hyperbaric therapy were noted.

The most common clinically significant complication in the short-term postoperative period ( $<30$ days) was pneumonia, which developed in 2 patients. A single patient developed pneumomediastinum, which was attributed to a partial dehiscence of the esophageal repair and responded well to esophageal stenting and antibiotics.

In long-term follow-up, the highest degree of mortality and morbidity was due to recurrent or progressive metastatic disease ( 3 patients; median survival, $\sim 120$ days). A patient with HIV who underwent airway reconstruction with acellular dermal matrix developed a significant esophageal stricture that required serial dilation and eventually stenting. He progressed to end-stage AIDs 6 years later and developed a recurrent bronchoesophageal fistula, eventually dying.

\section{DISCUSSION}

The goals of an airway repair, in the simplest terms, include maintenance of an airtight airway and development of respiratory epithelium to facilitate mucociliary clearance of the patient's airway secretions. The preferred method for correction of airway defects is primary resection and reconstruction. Through neck flexion, laryngeal release, airway mobilization, and hilar release defects up to $5 \mathrm{~cm}$ may be closed primarily in ideal patients. ${ }^{3}$ However, as the size of the defect increases so too does the risk of excessive anastomotic tension and with it risk of dehiscence and airway failure. Rarely, the complexity, size of the airway defect, and unique patient factors such as prior operative 
TABLE 2. Lesion characteristics

\begin{tabular}{|c|c|c|c|}
\hline Patient & Airway defect & Defect length, cm & Enteric fistula \\
\hline 1 & Left main stem bronchus & 3 & Yes \\
\hline 2 & Membranous wall of trachea & 4 & Yes \\
\hline 3 & Membranous wall of trachea & 2.5 & No \\
\hline 4 & Membranous wall of trachea & 6 & Yes \\
\hline 5 & Right bronchus intermedius; left main stem bronchus & $2.0 ; 1.0$ & Yes \\
\hline 6 & Membranous wall of trachea & 6 & Yes \\
\hline 7 & Cartilaginous wall of trachea & 6 & No \\
\hline 8 & Membranous wall of trachea & 5 & No \\
\hline
\end{tabular}

manipulation and exposure to radiation treatment preclude traditional management and alternative strategies must be employed. Patients in this rare category should be referred to a high-volume center for careful evaluation by a surgeon experienced in complex airway reconstruction before the decision to abandon primary repair is made. The work described above demonstrates that both aortic homograft and acellular dermal matrix are safe and reliable options for this group of patients with large, noncircumferential central airway defects deemed unsuitable for primary repair.
As has been shown previously, reconstruction with aortic homograft is associated with formation of granulation tissue. ${ }^{11}$ Our experience supports this finding, which highlights the importance of frequent surveillance bronchoscopy and debridement as necessary. Although human acellular dermis is often claimed to resist granulation formation and promote growth of epithelium, ${ }^{7}$ these patches were associated with granulation formation in our experience. The exact histologic basis of bioprosthetic incorporation and reepithelialization in these patients is still elusive and will require further study. What is apparent is that these 
TABLE 3. Operative management

\begin{tabular}{|c|c|c|c|c|c|}
\hline Patient & Approach & $\begin{array}{c}\text { Bioprosthetic } \\
\text { material }\end{array}$ & $\begin{array}{c}\text { Suture material for } \\
\text { bioprosthetic }\end{array}$ & Flap/mesh & Management enteric fistula \\
\hline 1 & Right thoracotomy & $\begin{array}{l}\text { Acellular dermal } \\
\text { matrix }\end{array}$ & Interrupted 4-0 Vicryl* & Latissimus dorsi & $\begin{array}{l}\text { 2-layer esophageal closure } \\
\text { with muscle flap buttress }\end{array}$ \\
\hline 2 & Right thoracotomy & Aortic homograft & Interrupted 4-0 Vicryl* & Omentum & $\begin{array}{l}\text { Partial resection of gastric } \\
\text { conduit and inferior } \\
\text { mobilization, } \\
\text { pharyngostomy }\end{array}$ \\
\hline 3 & Right thoracotomy & Aortic homograft & Interrupted 5-0 Vicryl* & Polypropylene mesh & None required \\
\hline 4 & Right thoracotomy & $\begin{array}{l}\text { Acellular dermal } \\
\text { matrix }\end{array}$ & Interrupted 3-0 Vicryl* & None & $\begin{array}{l}\text { Esophagectomy with cervica } \\
\text { esophagostomy }\end{array}$ \\
\hline 5 & Right thoracotomy & $\begin{array}{l}\text { Acellular dermal } \\
\text { matrix }\end{array}$ & Interrupted 4-0 Vicryl ${ }^{*}$ & $\begin{array}{l}\text { Latissimus dorsi, } \\
\text { Intercostal muscle }\end{array}$ & $\begin{array}{l}\text { Esophagectomy with cervica } \\
\text { esophagostomy }\end{array}$ \\
\hline 6 & $\begin{array}{l}\text { Cervical }+ \text { median } \\
\text { sternotomy }\end{array}$ & Aortic homograft & Interrupted 4-0 Vicryl* & Omentum & 2-layer esophageal closure \\
\hline 7 & Cervical & Aortic homograft & Interrupted 5-0 Vicryl* & Strap muscle & None required \\
\hline 8 & Right thoracotomy & Aortic homograft & Interrupted 5-0 Vicryl* & $\begin{array}{l}\text { Latissimus dorsi, } \\
\text { intercostal muscle }\end{array}$ & None required \\
\hline
\end{tabular}

*Ethicon Inc, Somerville, NJ.

bioprosthetics have greatly expanded our ability to address large and complex noncircumferential airway defects.

The use of muscle buttress in repair of large airway defects remains controversial. In the above study, selection was based on location of the lesion, availability of healthy nonirradiated tissue whose vascular pedicle could be preserved, and surgeon preference. Camargo and colleagues ${ }^{12}$ questioned the need for buttressing in the treatment of benign tracheoesophageal fistulas with traditional primary repair. However, in the case series presented herein the patient population differed in that patients frequently presented with complex defects that were associated with malignancy, prior surgical intervention, or failed repairs. Theoretically, the muscle buttress serves to secure the repair in the event of a leak, separate suture lines when both airway and esophagus are repaired, and to support the bioprosthetic material to

TABLE 4. Bioprosthetic performance and postoperative functional status

\begin{tabular}{|c|c|c|c|c|c|c|c|c|c|}
\hline Patient & $\begin{array}{c}\text { Granulation } \\
\text { tissue }\end{array}$ & $\begin{array}{c}\text { Further } \\
\text { intervention }\end{array}$ & $\begin{array}{c}\text { Total/ } \\
\text { postoperative/ } \\
\text { intensive care } \\
\text { unit length } \\
\text { of stay, d }\end{array}$ & $\begin{array}{l}\text { Postoperative } \\
\text { tracheostomy }\end{array}$ & Decannulation & $\begin{array}{r}\text { Resumption } \\
\text { of oral diet }\end{array}$ & $\begin{array}{c}\begin{array}{c}\text { Tube } \\
\text { feed } \\
\text { dependent }\end{array} \\
\end{array}$ & $\begin{array}{l}\text { Disposition } \\
\text { at discharge }\end{array}$ & Follow-up \\
\hline 1 & Yes & $\begin{array}{l}\text { Debridement of } \\
\text { granulation } \\
\text { tissue }\end{array}$ & $30 / 24 / 2$ & No & NA & Yes & No & Home & $\begin{array}{l}\text { Died of end-stage } \\
\text { AIDS at } 6 y\end{array}$ \\
\hline 2 & Yes & $\begin{array}{l}\text { Debridement of } \\
\text { granulation } \\
\text { tissue }\end{array}$ & $51 / 29 / 5$ & Yes & No & No & Yes & Home & $\begin{array}{l}\text { Died of squamous } \\
\text { cell carcinoma } \\
\text { at } 6 \text { mo }\end{array}$ \\
\hline 3 & Yes & No & $8 / 7 / 2$ & No & NA & Yes & No & Home & $\begin{array}{l}\text { Repair intact at } \\
5 \mathrm{y}\end{array}$ \\
\hline 4 & NA* & No & $29 / 22 / 10$ & Yes & Yes & Yes & No & $\begin{array}{c}\text { Rehabilitation } \\
\text { Facility }\end{array}$ & $\begin{array}{l}\text { Died of squamous } \\
\text { cell carcinoma } \\
\text { at } 4 \text { mo }\end{array}$ \\
\hline 5 & Yes & No & $44 / 29 / 17$ & Yes & No & Yes & Yes & $\begin{array}{l}\text { Rehabilitation } \\
\text { facility }\end{array}$ & $\begin{array}{l}\text { Died of squamous } \\
\text { cell carcinoma } \\
\text { at } 2 \text { mo }\end{array}$ \\
\hline 6 & Yes & No & $71 / 41 / 9$ & Yes $\dagger$ & $\mathrm{No} \dagger$ & $\mathrm{No} \dagger$ & Yes $\dagger$ & $\begin{array}{c}\text { Rehabilitation } \\
\text { Facility }\end{array}$ & $\begin{array}{l}\text { Repair intact at } \\
1.5 \mathrm{y}\end{array}$ \\
\hline 7 & Yes & $\begin{array}{r}\text { Dilation of } \\
\text { stricture }\end{array}$ & $15 / 14 / 9$ & Yes & Yes & Yes & No & Home & $\begin{array}{l}\text { Repair intact at } \\
5 \mathrm{y}\end{array}$ \\
\hline 8 & Yes & No & $15 / 14 / 2$ & No & NA & Yes & No & Home & $\begin{array}{l}\text { Repair intact at } \\
1 \mathrm{y}\end{array}$ \\
\hline
\end{tabular}

$N A$, Not applicable. *No further bronchoscopy was performed after initial surgery. $\nmid$ Previous tracheostomy and tube-feed-dependent secondary stroke. 


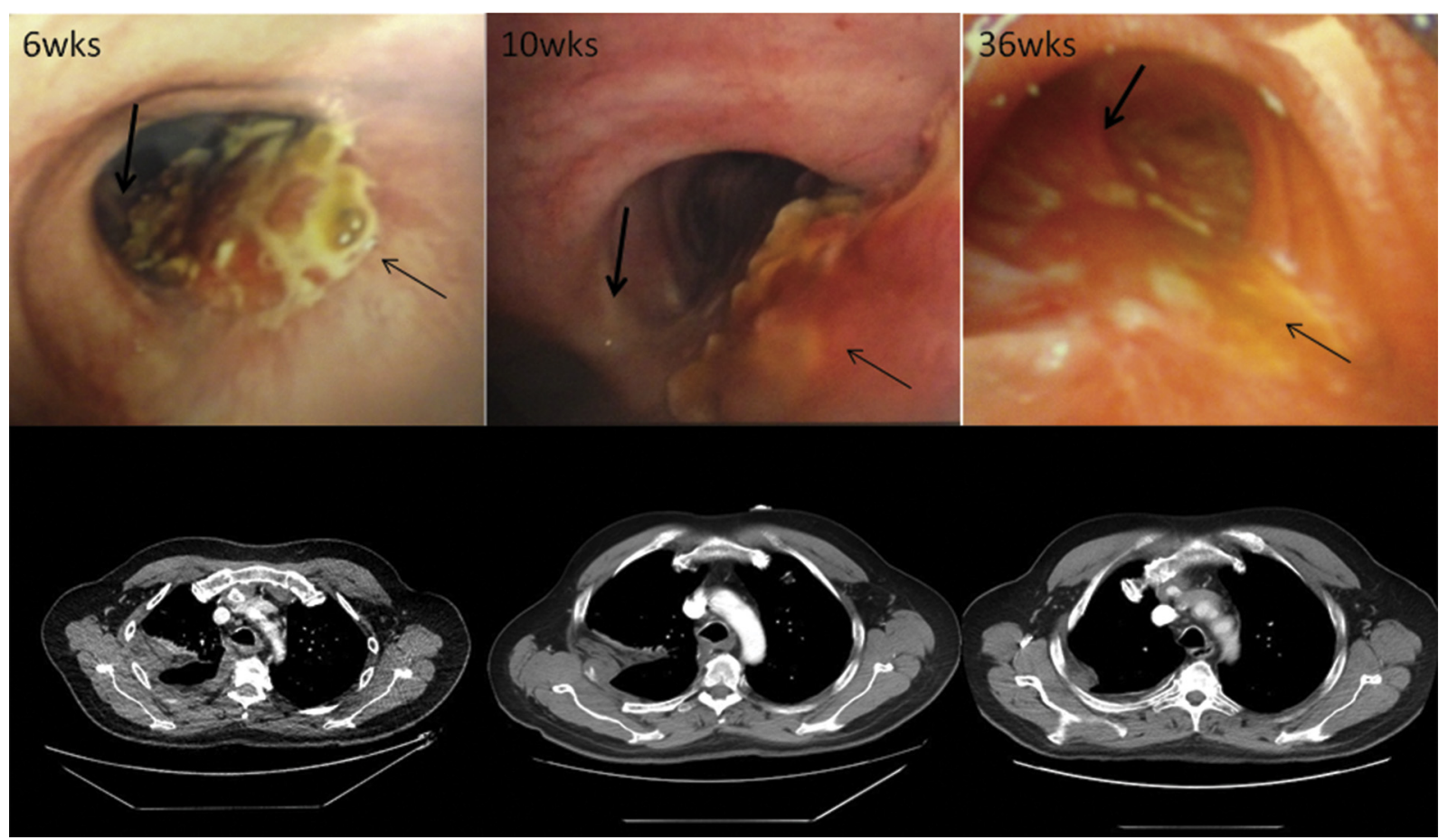

FIGURE 3. Aortic homograft repair (small arrow) extending just proximal to the carina (large arrow) as visualized by bronchoscope at 6 weeks, 10 weeks, and 36 weeks along with similarly timed computed tomography scans. The graft was well incorporated with granulation tissue and no evidence of stricture or malacia was present.

prevent malacia. ${ }^{9,13}$ In addition, the muscle provides insurance should the bioprosthetic dehisce or necrose altogether. Use of muscle flaps alone in repair of large airway defects was reported by Meyer and colleagues ${ }^{14}$ with excellent short-term results. However, larger defects that involved between $30 \%$ and $50 \%$ of the airway required muscle transposition with an embedded rib segment. Moreover, these repairs required the use of a Y-stent for several weeks postoperatively to prevent airway collapse. ${ }^{14}$

We have previously suggested that HBOT, with its ability to promote angiogenesis and collagen synthesis, could be an important adjunct in managing a compromised tracheal anastomosis. We observed that in 5 patients with anastomotic complications after tracheal resection and reconstruction, HBOT was associated with airway healing and prevented reoperation or tracheostomy. ${ }^{15}$ It is reasonable to speculate that HBOT could also enhance rapid tissue ingrowth, vascularization, and incorporation of the bioprosthetic materials used to reconstruct the airway, as was observed in a patient in this series. It remains to be seen if HBOT should be initiated routinely after bioprosthetic reconstruction of an airway.
Major limitations include a relative dearth of hyperbaric oxygen chambers as well as the prolonged isolation within the chamber required for treatment. Only stable patients without evidence of hemodynamic or respiratory instability should be offered this treatment.

Treatment of large airway defects and fistulas with stents has been reported, but for the most part as a palliative or temporizing measure, before surgical treatment. ${ }^{16,17}$ Control of tracheoesophageal fistula has been reported using covered, self-expanding stents in 2 of 4 patients by Blackmon and colleagues, ${ }^{18}$ although long-term durability was not established. Moreover, esophageal stenting has been reported as an independent cause of tracheoesophageal fistula through tissue erosion. ${ }^{2,19}$ In the present study, 3 patients failed stenting procedures either through inadequate seals or stent erosion before referral. In patients with isolated tracheal or bronchial lesions, those larger than $2 \mathrm{~cm}$ are unlikely to heal without surgical intervention. ${ }^{20}$ Stenting procedures in patients with extremely large airway defects are unlikely to provide an adequate seal or achieve definitive healing of the airway.

TABLE 5. Performance of human acellular dermis versus aortic homograft

\begin{tabular}{lccrr}
\hline & $\begin{array}{c}\text { Short-term } \\
\text { complication rate }\end{array}$ & $\begin{array}{c}\text { Presence of } \\
\text { granulation tissue }\end{array}$ & Recurrence & $\begin{array}{c}\text { Long-term } \\
\text { mortality }\end{array}$ \\
\hline Acellular dermal matrix & 66 & 100 & 33 & 100 \\
Aortic homograft & 20 & 100 & 0 & 1973 \\
\hline
\end{tabular}

Values are presented as $\%$ or, for cost, $\$$. 
In cases in which definitive repair is delayed either due to infection or other underlying disease, a tracheal or esophageal stent may be beneficial, but should be used with caution and frequent surveillance because these devices have the potential to erode and further increase the size of the defect.

Alternative methods of repair for extensive tracheal defects have been described, including radial forearm free flaps. ${ }^{13,21,22}$ However, such repairs require extensive use of microsurgical techniques as well as placement of prosthetic materials and mesh. The complexity of these techniques limits their use, as does the reliability of the vascular supply in previously irradiated fields. Moreover, the harvesting of radial forearm free flaps introduces donor site morbidity to the procedure. Although in certain cases these repairs may be beneficial in the hands of experienced clinicians, they have been associated with a relative high rate of air leak occurring in 4 of 7 patients reported by Yu and colleagues. ${ }^{13}$ In 2 of those cases further operative intervention was required. ${ }^{13}$

Finally, vacuum-assisted closure devices have been reported in the treatment of infected postpneumonectomy chest cavities and bronchopleural fistula. ${ }^{23}$ Unfortunately, the application of such devices in the closure the large tracheal and bronchial defects described herein is limited by the size, anatomic location of the lesions, and presence of volume-occupying pulmonary tissue. Moreover, these devices require an open chest wound, which adds significant morbidity to the procedure. Other devices used in the closure of bronchopleural fistula such as septal occlusion devices are limited, given the size of the lesions described herein. Although occlusion devices have been reported in the successful closure of postpneumonectomy bronchopleural fistula, those fistulas typically span several millimeters. ${ }^{24}$ In contrast, the tracheal and bronchial defects described in this work are several centimeters in length.

In the present study, there is no apparent advantage of one bioprosthetic over the other (Table 5). Both served as safe and effective airway patches, although the cost of aortic homograft is significantly more than acellular dermal matrix. Bovine pericardium, an alternative bioprosthetic material, was not explored in this study due to concerns of its longterm durability and propensity for calcification. Although large airway defects are associated with a high degree of morbidity and mortality, bioprosthetic repairs with aortic homograft and acellular dermal matrix offer the potential for a long-term and definitive correction in these difficult situations. It should be emphasized that these bioprosthetic materials should not replace traditional primary repair. Primary repair remains the first-line treatment for defects of the central airway. Only in the rare circumstances in which a defect's size and/or complexity preclude traditional repair should these bioprosthetics be used as a last resort for closure of the airway. The decision to abandon primary repair should be made by a surgeon experienced in complex airway repair at a high-volume center. In general, defects $>$ $5 \mathrm{~cm}$ preclude primary repair due to excessive anastomotic tension; however, specific patient variables such as a lesion's proximity to the carina, prior operative intervention, and exposure to radiation treatment can introduce additional challenges to a primary repair.

As these bioprosthetics become more widely used, it will be important to assess their durability. This is especially true when used in patients with malignancies that require further tissue-damaging chemotherapy or radiation therapy that have the potential to compromise any surgical repair. At this time, the effect of chemotherapy and radiation on angiogenesis, granulation formation, and epithelialization within a bioprosthetic repair is largely unknown. Furthermore, the dichotomy in outcomes of patients undergoing airway repair for benign disease versus malignant squamous cell carcinoma is notable, with a median survival of 4 months in the later case. In these patients with later-stage malignant disease, careful discussion among the surgeon, patient, and patient's family members should take place. Moreover, it is prudent to take a multidisciplinary approach, including conversations with a patient's oncology team and, when appropriate, palliative care team. Bioprosthetic materials can offer relief in difficult situations; however, cure may not be possible and the associated morbidity of a thoracotomy and complex airway repair may not be the correct treatment option depending on the goals of care of the individual patient.

\section{CONCLUSIONS}

Although our results are derived from a limited number of heterogeneous patients, they suggest that closure of noncircumferential large airway defects with bioprosthetic materials is feasible, safe, and reliable. In patients for whom primary repair is not feasible due to either the size or complexity of the defect, these bioprosthetics offer a potential solution.

\section{Webcast}

You can watch a Webcast of this AATS meeting presentation by going to: http://webcast.aats.org/2016/Video/ Tuesday/05-17-16_Room_337_0730_Udelsman-800.mp4.

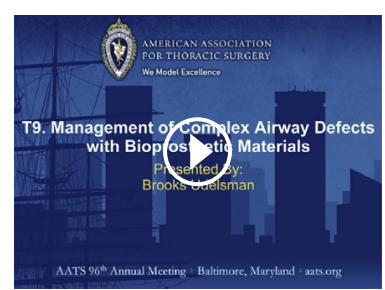

\section{Conflict of Interest Statement}

Authors have nothing to disclose with regard to commercial support. 


\section{References}

1. Shen KR, Allen MS, Cassivi SD, Nichols FC III, Wigle DA, Harmsen WS, et al Surgical management of acquired nonmalignant tracheoesophageal and bronchoesophageal fistulae. Ann Thorac Surg. 2010;90:914-8; discussion 919.

2. Muniappan A, Wain JC, Wright CD, Donahue DM, Gaissert H, Lanuti M, et al. Surgical treatment of nonmalignant tracheoesophageal fistula: a thirty-five year experience. Ann Thorac Surg. 2013;95:1141-6.

3. Grillo HC. Tracheal replacement: a critical review. Ann Thorac Surg. 2002;73: 1995-2004.

4. Thomas M, Allen MS, Shen KR, Wigle DA. A novel use of human acellular dermis for conduit salvage after esophagectomy. Ann Thorac Surg. 2014;97:1459-63.

5. Sinha UK, Chang KE, Shih CW. Reconstruction of pharyngeal defects using AlloDerm and sternocleidomastoid muscle flap. Laryngoscope. 2001;111(11 pt 1):1910-6.

6. Chahine AA, Tam V, Ricketts RR. Use of the aortic homograft in the reconstruction of complex tracheobronchial tree injuries. J Pediatr Surg. 1999;34:891-4.

7. Livesey SA, Herndon DN, Hollyoak MA, Atkinson YH, Nag A. Transplanted acellular allograft dermal matrix. Potential as a template for the reconstruction of viable dermis. Transplantation. 1995;60:1-9.

8. Morse CR. Repair of bronchial esophageal fistula using Alloderm. Ann Thorac Surg. 2009;88:1018-9.

9. Su JW, Mason DP, Murthy SC, Rice TW. Closure of a large tracheoesophageal fistula using AlloDerm. J Thorac Cardiovasc Surg. 2008;135:706-7.

10. Reames BN, Lin J. Repair of a complex bronchogastric fistula after esophagectomy with biologic mesh. Ann Thorac Surg. 2013;95:1096-7.

11. Zeitels SM, Wain JC, Barbu AM, Bryson PC, Burns JA. Aortic homograft reconstruction of partial laryngectomy defects: a new technique. Ann Otol Rhinol Laryngol. 2012;121:301-6.

12. Camargo JJ, Machuca TN, Camargo SM, Lobato VF, Medina CR. Surgical treatment of benign tracheo-oesophageal fistulas with tracheal resection and oesophageal primary closure: is the muscle flap really necessary? Eur J Cariothorac Surg. 2010;37:576-80.

13. Yu P, Clayman GL, Walsh GL. Long-term outcomes of microsurgical reconstruction for large tracheal defects. Cancer. 2011;117:802-8.

14. Meyer AJ, Krueger T, Lepori D, Dusmet M, Aubert JD, Pasche P, et al. Closure of large intrathoracic airway defects using extrathoracic muscle flaps. Ann Thorac Surg. 2004;77:397-404; discussion 405.

15. Stock C, Gukasyan N, Muniappan A, Wright C, Mathisen D. Hyperbaric oxygen therapy for the treatment of anastomotic complications after tracheal resection and reconstruction. J Thorac Cardiovasc Surg. 2014;147:1030-5.

16. Eleftheriadis E, Kotzampassi K. Temporary stenting of acquired benign tracheoesophageal fistulas in critically ill ventilated patients. Surg Endosc. 2005;19:811-5.

17. Wang F, Yu H, Zhu MH, Li QP, Ge XX, Nie JJ, et al. Gastrotracheal fistula: treatment with a covered self-expanding Y-shaped metallic stent. World J Gastroenterol. 2015;21:1032-5.

18. Blackmon SH, Santora R, Schwarz P, Barroso A, Dunkin BJ. Utility of removable esophageal covered self-expanding metal stents for leak and fistula management. Ann Thorac Surg. 2010;89:931-6; discussion 936-7.

19. Han Y, Liu K, Li X, Wang X, Zhou Y, Gu Z, et al. Repair of massive stent-induced tracheoesophageal fistula. J Thorac Cardiovasc Surg. 2009;137:813-7.

20. Mullan GP, Georgalas C, Arora A, Narula A. Conservative management of a major post-intubation tracheal injury and review of current management. Eur Arch Otorhinolaryngol. 2007;264:685-8.

21. Maciejewski A, Szymczyk C, Poltorak S, Grajek M. Tracheal reconstruction with the use of radial forearm free flap combined with biodegradative mesh suspension. Ann Thorac Surg. 2009;87:608-10.

22. Mitchell JD, Mathisen DJ, Wright CD, Wain JC, Donahue DM, Moncure AC, et al. Clinical experience with carinal resection. J Thorac Cardiovasc Surg. 1999; 117:39-52; discussion 53.

23. Perentes JY, Abdelnour-Berchtold E, Blatter J, Lovis A, Ris HB, Krueger T, et al. Vacuum-assisted closure device for the management of infected postpneumonectomy chest cavities. J Thorac Cardiovasc Surg. 2015;149:745-50.

24. Gulkarov I, Paul S, Altorki NK, Lee PC. Use of Amplatzer device for endobronchial closure of bronchopleural fistulas. Interact Cardiovasc Thorac Surg. 2009; 9:901-2.

Key Words: large airway defects, acellular dermal matrix, aortic homograft, bioprosthetic

\section{Discussion}

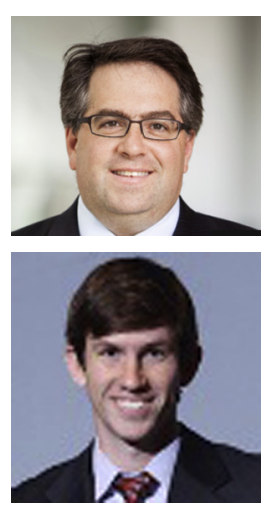

Dr Justin T. Sambol (Newark, NJ). When you put in this matrix or aortic homograft, do you ever leave a stent as well, or do you just put it in?

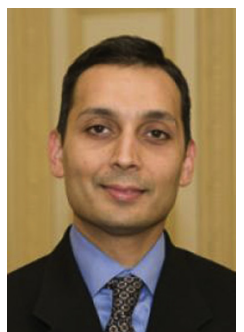

Dr Faiz Y. Bhora (New York, NY). I have 2 questions. The source of your acellular dermis, is that human, is that porcine, or is that bovine, and what thickness did you use?

Dr Udelsman. Human and extra-thick, 2.3 to $3.3 \mathrm{~mm}$ in thickness.

Dr Bhora. My understanding is that the human is not more than $1 \mathrm{~mm}$ in thickness and that the thickest really is bovine, but maybe you can correct me on that.

Dr Udelsman. I believe the extra-thick commercially available product is.

Dr Bhora. In your series did you see any difference between the homograft, which is obviously much thicker, and the acellular dermis? What would be your advice in that regard if you had to use one or the other material?

Dr Udelsman. We did not see a real difference in our series, although it was small in number, but in terms of recommendation, it would be surgeon preference and experience which material the surgeon is most comfortable with and has used previously.

Dr Bhora. Finally, the concern, obviously, with the dermis is that eventually it tends to disappear, or that is the concept. It is not meant to be a bridge; that is, to bridge tissue. That is not the indication for it. So perhaps there is some tissue ingrowth that is happening. Maybe some stem cells have been recruited. What is your hypothesis for its long-term integrity over 2 to 6 years?

Dr Udelsman. I think it likely serves as sort of a scaffold for tissue ingrowth and contraction. We see fibrosis and scarring, and it serves as a scaffold for tissue ingrowth, as you mentioned. I don't believe it actually turns into trachea, but it allows a natural healing process to continue.

Dr Bhora. Very nice work.

Dr Udelsman. Thank you. 


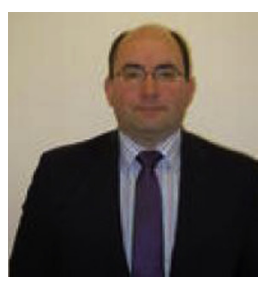

Dr David A. Waller (Leicester, United Kingdom). Could you hypothesize about the use of this in the repair of postpneumonectomy bronchopleural fistula?

Dr Udelsman. It would be a potential area, but I really wouldn't know. In this series we primarily just looked at tracheal and main stem bronchus injuries. It is likely to be used in many settings. The versatility of it has been seen all over. It is used in many different applications.

Dr Waller. You have not tried it in that situation?

Dr Udelsman. No.

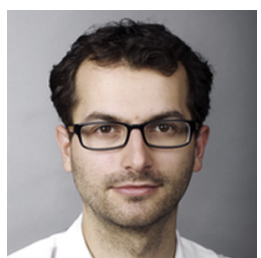

Dr Konrad Hoetzenecker (Vienna, Austria). I have just 2 short questions.

First, you are probably aware that the French Group for Airway Transplantation has done 6 human cases and in 3 of those cases they found a tracheoesophageal fistula in the long term. What are your thoughts when you look at your patients? The second question is, Did you find regeneration of cartilage inside your aortic replacements?

Dr Udelsman. We did see a case of recurrent tracheoesophageal fistula or bronchoesophageal fistula, but it was 6 years after initial repair in the setting of severe inflammation and in end-stage AIDS. It was an immunocompromised patient. We didn't see any other examples of that in our series.

Can you repeat your second question?

Dr Hoetzenecker. Do you see any cartilage formation? At least in pig models, newly formed cartilage was seen in the aortic graft.

Dr Udelsman. We did not see any in our series. We did see surface granulation on biopsy, but we did not see cartilage developing over this.

Dr Hoetzenecker. Thank you. 